\title{
The Effect of Algan Hemostatic Agent (AHA) on Wound Healing
}

\author{
Halil Aksoy ${ }^{1}$, Azize Sener ${ }^{1}$ (D), Dilek Akakin² (D), Ali Sen ${ }^{3}$ (D) Ozlem Bingol Ozakpinar ${ }^{1}$ (D), Sinemcan Ozcan² (D), Ahmet \\ Kaan Simsek ${ }^{4}$, Turgut Sekerler ${ }^{1}$ (D) , Sevket Ergun Guzel ${ }^{5}$ (D), Ahmet Midi6 \\ ${ }^{1}$ Marmara University, Faculty of Pharmacy, Department of Biochemistry, İstanbul, Turkey. \\ ${ }^{2}$ Marmara University, Faculty of Medicine, Department of Histology-Embryology, İstanbul, Turkey. \\ ${ }^{3}$ Marmara University, Faculty of Pharmacy, Department of Pharmacognosy, İstanbul, Turkey. \\ ${ }^{4}$ Bahcesehir University, Faculty of Medicine, İstanbul, Turkey. \\ ${ }^{5}$ Kahta State Hospital, Department of Orthopedics, Adiyaman, Turkey. \\ ${ }^{6}$ Bahcesehir University, Faculty of Medicine, Department of Pathology, İstanbul, Turkey.
}

Correspondence Author: Halil Aksoy

E-mail: aksoyhalil@yahoo.com

Received: 10.08 .2020

Accepted: 04.09 .2020

\begin{abstract}
Objective: The Algan Hemostatic Agent (AHA) is a novel herbal originated blood stopper. The aim of this study is to investigate the effect of AHA on wound healing on excisional wound model in rats.

Methods: In this study, 54 adult Wistar albino rats were used. Rats were divided into 3 groups (saline, Madecassol ${ }^{\circledR}$ and AHA). Each group was then divided into 3 subgroups as the $3^{\text {rd }}, 7^{\text {th }}$ and $14^{\text {th }}$ days. Two wounds were created in the dorsal thoracic region of the rats. One of the lesions was used for histopathological examinations and the other for hydroxyproline measurement. In order to evaluate the wound healing, wound area were measured during the whole treatment period and animals were sacrificed at the end of the $3^{\text {rd }}, 7^{\text {th }}$ and $14^{\text {th }}$ days and tissue samples were taken for the determination of hydroxyproline levels.

Results: AHA treatment did not cause significant difference in hydroxyproline level on days $3,7,14$. The contraction percentage of wound area was higher in the AHA group on day 7 than that of the control group. However, the difference was not statistically significant ( $p>0.05)$. On days 3 and 14, no significant difference was detected in the contraction percentage of wound area between the control and the AHA groups. AHA and Madecasso ${ }^{\circledast}$ results of epidermis regeneration on the $14^{\text {th }}$ day, neutrophil infiltration on the $7^{\text {th }}$ day and edema on the $3^{\text {rd }}, 7^{\text {th }}$ and $14^{\text {th }}$ days were different in terms of histopathological parameters compared to the control group.
\end{abstract}

Conclusion: Despite good histological findings, AHA did not significantly accelerate wound healing, but did not adversely affect wound healing as well.

Keywords: Algan hemostatic agent, Madecassol ${ }^{\circledR}$, wound healing, hydroxyproline

\section{INTRODUCTION}

Wound healing is a complex physiological process involving soluble mediators, blood cells, and extracellular matrix in damaged tissue. It consists of four programmed phases as hemostasis, inflammation, proliferation, and tissue remodeling (1). The presence of certain factors such as diabetes, obesity, infection, aging, stress, defiency of steroids such as observed in postmenopausal period, and poor nutrition impair wound healing processes (2). It is important for proper wound healing to be rapid without infection and not leave a scar tissue. If the contraction of the scar tissue formed in the final stage of wound healing is excessive, it may also causes deformities in the internal organs (3). Different local and systemic therapies are being investigated to accelerate wound healing. Some extracts obtained from species such as Aesculus hippocastanum, Cotinus coggygria and bioactive molecules have been reported to accelerate the wound healing process by promoting collagen deposition, increasing fibroblasts, preventing infection or suppressing oxidative stress (4-7).

The Algan hemostatic agent (AHA, Algan Group Health Services Import and Export Industry and Trade Ltd., Co., Istanbul, Turkey) is a novel polysaccharide based hemostatic agent and has been patented (Patent application no: a2015 / 00018, application publication no. TR2015 0018 A2). It is in the form of powder, and liquid and produced for bleeding control. It consists of a standardized mixture of 6 different plants (Achillea millefolium, Juglans regia, Lycopodium clavatum, Rubus caesius, Viscum album, Vitis vinifera). Preclinical studies of AHA have been completed and clinical studies are continuing. It has been shown to be 
effective in some bleeding models like experimental partial splenoctomy (8), renal venous bleeding (9), liver laceration (10) and hepatectomy bleeding (11). According to the hemodynamic test, AHA primarily provides hemostasis by forming a mechanical barrier in the area where it is applied (9). It has been reported that the coagulation mechanism forms by confining and gelling blood elements into the polymeric network (12). AHA has a similar mechanism of action with polymer-based hemostatic products $(8,9)$. Local hemostatic (antihemorrhagic) agents promote hemostasis in postoperative and posttraumatic bleeding. An ideal hemostatic agent should be safe. A hemostatic agent is expected to have a positive effect on wound healing or at least not to have a negative effect. Besides their favourable hemostatic effects, some hemostatic agents are shown to accelarete wound healing (13-15).

In this study, we aimed to investigate time-dependent effects of AHA on wound healing on the excisional wound model created in rats. The effects of AHA on wound healing is important because it is a product that will be used as a local hemostatic agent in internal and external bleedings.

\section{MATERIALS AND METHODS}

\subsection{Animals}

In this study, female Wistar albino rats, weighing 250-300 $\mathrm{g}$ and 16 weeks old, were used. Rats were obtained from Marmara University Experimental Animal Research and Application Center. The animals were kept in individual wirebottomed cages, in a room at a constant temperature $\left(22^{\circ} \pm\right.$ $2^{\circ} \mathrm{C}$ ) with 12 -h light and dark periods, and fed with standard rat chow. All procedures for the experimental protocols of this study were approved by the Marmara School of Medicine Animal Care and Use Ethics Committee (protocol number: 15.2020.mar). During the experiments, all animals were subjected to the same stress under the same conditions.

\subsection{Treatments}

Test agent, Algan Hemostatic Agent, was obtained from Algan Group Health Services Import and Export Industry and Trade Ltd., Co., Istanbul, Turkey. The rats were divided into the following three groups of eighteen rats each: Control group, AHA treatment group, Madecassol ${ }^{\circledR}$ (Bayer, as reference oinment) treatment group. Each group was then divided into 3 subgroups (as the $3^{\text {rd }}, 7^{\text {th }}$ and $14^{\text {th }}$ days), each consisting of six rats.

\subsection{Excisional Wound Model}

This model is a convenient method to monitor wound contraction. The study was conducted as described in the literature (6). Under anesthesia, the dorsal region hairs of rats were removed with shaving machine and the wound area was cleaned with $0.2 \%$ chlorhexidine solution. Two circular wounds were excised from the skin with a $6 \mathrm{~mm}$ biopsy punch to create wounds in the dorsal thoracic region of each animal. The wounds were left open throughout the study. The progressive changes in wound area of all groups were monitored.

Saline was administered topically once daily to the control group. AHA solution (liquid form) and Madecassol ${ }^{\circledR}$ (Bayer) were also applied topically once daily. These applications were continued until the end of the $3^{\text {rd }}, 7^{\text {th }}$ and $14^{\text {th }}$ days. Tissue samples were taken at the end of the experiment. One of the two wound tissues created in each animal was used for the determination of hydroxyproline content and the other for histopathological examinations.

\subsection{The contraction Percentage of Wound Area}

In order to evaluate the contraction percentage of the wound areas, sizes of wounds were measured on the end of days 3,7 , and 14 . The shape of each wound was drawn on transparent paper. Then, wound shapes were transferred on a $1 \mathrm{~mm}$ chart paper. The contraction percentage of wound area was calculated by using the following formula (16). The contraction percentage of wound area $=($ initial wound size specific day wound size)/initial wound size) $\times 100$.

\subsection{Determination of Hydroxyproline Content}

Tissue samples were taken at the end of the $3^{\text {rd }}, 7^{\text {th }}$ and $14^{\text {th }}$ days. Hydroxyproline content was measured using the method by Reddy and Enwemeka (17). Briefly, tissue samples were mixed with $2 \mathrm{~N} \mathrm{NaOH}$ and incubated for 20 minutes at $120{ }^{\circ} \mathrm{C}$. The samples were oxidized with chloramine $\mathrm{T}$ and Ehrlich reagent was added. Then, the absorbance of the coloured product formed at $65{ }^{\circ} \mathrm{C}$ was read at $550 \mathrm{~nm}$. The concentration of hydroxyproline was calculated using the standard curve. The results were presented as $\mathrm{mg} / \mathrm{g}$ tissue.

\subsection{Histological Scoring}

For histological examination, at the end of the $3^{\text {rd }}, 7^{\text {th }}$ and $14^{\text {th }}$ days wounded skin specimens were collected from the experimental groups and fixed in $10 \%$ neutral buffered formalin solution. After fixation, tissue samples were dehydrated in graded ethanol series $(70 \%, 90 \%, 96 \%$ and $100 \%)$, cleared in toluene and mounted in paraffin. Sections were cut into $4-\mu \mathrm{m}$-thick sections by rotary microtome from paraffin-embedded blocks and stained with hematoxylin and eosin (H\&E). Finally, the sections were viewed under a light microscope (Olympus BX51, Tokyo, Japan) for epidermal and dermal regeneration, fibroblast density, angiogenesis, neutrophil infiltration and edema scored semiquantitatively by two blinded histologists according to the scoring system outlined in Table 1. 
Table 1. System for Scoring the Histological Features of Wound Tissue Samples.

\begin{tabular}{|c|c|c|c|c|c|}
\hline Score & $\begin{array}{l}\text { Epidermal } \\
\text { and dermal } \\
\text { regeneration }\end{array}$ & $\begin{array}{l}\text { Fibroblast } \\
\text { density }\end{array}$ & Angiogenesis & $\begin{array}{l}\text { Neutrophil } \\
\text { infiltration }\end{array}$ & Edema \\
\hline 1 & $\begin{array}{l}\text { Little } \\
\text { epidermal } \\
\text { and dermal } \\
\text { organization }\end{array}$ & $\begin{array}{l}\text { Mild } \\
\text { fibroblast } \\
\text { density }\end{array}$ & $\begin{array}{l}\text { Altered } \\
\text { angiogenesis } \\
\text { (1-2 vessels } \\
\text { per site) }\end{array}$ & Mild & Mild \\
\hline 2 & $\begin{array}{l}\text { Moderate } \\
\text { epidermal } \\
\text { and dermal } \\
\text { organization }\end{array}$ & $\begin{array}{l}\text { Moderate } \\
\text { fibroblast } \\
\text { density }\end{array}$ & $\begin{array}{l}\text { Few newly } \\
\text { formed } \\
\text { capillary } \\
\text { vessels } \\
\text { (3-6 vessels } \\
\text { per site) }\end{array}$ & Moderate & Moderate \\
\hline 3 & $\begin{array}{l}\text { Complete } \\
\text { remodeling } \\
\text { of epidermis } \\
\text { and dermis }\end{array}$ & $\begin{array}{l}\text { Increased } \\
\text { fibroblast } \\
\text { density }\end{array}$ & $\begin{array}{l}\text { Newly } \\
\text { formed } \\
\text { capillary } \\
\text { vessels } \\
\text { (7-10 vessels } \\
\text { per site) }\end{array}$ & Severe & Severe \\
\hline 4 & & & $\begin{array}{l}\text { Newly } \\
\text { formed } \\
\text { and well- } \\
\text { structured } \\
\text { capillary } \\
\text { vessels } \\
\text { (>10 vessels } \\
\text { per site) }\end{array}$ & & \\
\hline
\end{tabular}

\subsection{Statistical Analysis}

Data were analyzed using GraphPad Prism 4.0 (La Jolla, CA). Statistical differences between groups were evaluated by one-way ANOVA and Tukey's post-hoc test. Data were expressed as mean \pm standard deviation (SD). A $p$ value $<0.05$ was considered as statistical significance.

\section{RESULTS}

The wound closure values and hydroxyproline levels of control, AHA and Madecassol ${ }^{\circledR}$ treated groups were as shown in Table 2. The contraction percentages of wound areas were observed as $43.83 \%, 74.34 \%$, and $86.57 \%$ at the end of the $3^{\text {rd }}, 7^{\text {th }}$ and $14^{\text {th }}$ days in the AHA group, respectively. The contraction percentages of wound areas of the AHA group were close to those of the control group on the $3^{\text {rd }}$ and the $14^{\text {th }}$ days, whereas the contraction percentages of wound areas of the AHA group on the $7^{\text {th }}$ day was $16 \%$ higher than those of the control group. However, this difference was not statistically significant. In the reference drug Madecassol $^{\circledR}$ group, the contraction percentages of wound areas were higher on the $7^{\text {th }}$ day compared to those of the control group, whereas they were higher on the $14^{\text {th }}$ day compared to those of the control and the AHA groups ( $p<0.05, p<0.01$ respectively). Figure 1 shows the wound images of rats randomly selected from each group.
Table 2. Wound Tissue Hydroxyproline Levels and Contraction Rates of Wound Areas (\%) of the Control and the Treatment Groups.

\begin{tabular}{|c|c|c|}
\hline & $\begin{array}{c}\text { Hydroxyproline } \\
\text { (mg/g tissue), } \\
\text { mean (SD) }\end{array}$ & $\begin{array}{c}\text { Contraction rate of wound } \\
\text { area (\%), } \\
\text { mean (SD) }\end{array}$ \\
\hline \multicolumn{3}{|c|}{$3^{\text {rd }}$ day } \\
\hline Control & $24.74 \pm 4.88$ & $47.33 \pm 14.45$ \\
\hline $\mathrm{AHA}$ & $24.16 \pm 1.53$ & $43.83 \pm 4.50$ \\
\hline Madecassol $^{\circledR}$ & $32.14 \pm 5.81^{*}, \neq$ & $48.67 \pm 3.30$ \\
\hline \multicolumn{3}{|c|}{$7^{\text {th }}$ day } \\
\hline Control & $26.50 \pm 4.50$ & $64.00 \pm 2.76$ \\
\hline AHA & $29.65 \pm 2.37$ & $74.34 \pm 9.00$ \\
\hline Madecassol ${ }^{\circledR}$ & $31.21 \pm 4.85$ & $78.86 \pm 3.24 *$ \\
\hline \multicolumn{3}{|c|}{$14^{\text {th }}$ day } \\
\hline Control & $24.80 \pm 1.21$ & $88.00 \pm 4.78$ \\
\hline $\mathrm{AHA}$ & $22.97 \pm 2.40$ & $86.57 \pm 6.03$ \\
\hline Madecassol $^{\circledR}$ & $24.89 \pm 1.66$ & $95.00 \pm 1.44^{*}, \neq \neq$ \\
\hline
\end{tabular}

${ }^{*} p<0.05$, versus control group; ${ }^{\ddagger} p<0.05,{ }^{\not \neq} p<0.01$ versus AHA group; SD: standard deviation; AHA: Algan Hemostatic Agent

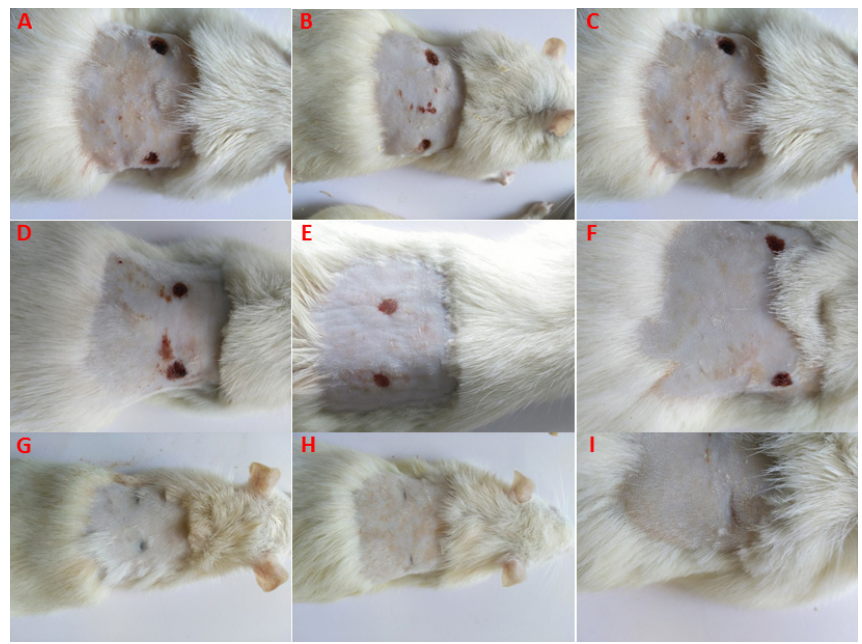

Figure 1. The wound images of randomly selected rats from each group. A, B, C: $3^{\text {rd }}$ day; $D, E, F: 7^{\text {th }}$ day; $G, H, I: 14^{\text {th }}$ day. On day 3 , the wound closure was similar in all groups.

Hydroxyproline levels of the AHA group on days 3 and 14 were close to those of the control group. There was no difference between hyroxyproline levels of the control and the AHA groups on day 7. However, hyroxyproline level of the AHA group was found to be higher than that of the control group. Hydroxyproline levels of the Madecassol ${ }^{\circledR}$ group on day 3 were significantly higher than those of the control and the AHA groups $(p<0.05)$. No significant difference was observed in the hydroxyproline levels of the Madecassol ${ }^{\circledR}$ group on days 7 and 14 compared to those of the AHA and control groups.

There was no difference between the groups regarding the histopathological parameters evaluated in terms of epidermis regeneration, on the $3^{\text {rd }}$ and $7^{\text {th }}$ days. However, on the $14^{\text {th }}$ day, histopathological parameters of the Madecasso ${ }^{\circledR}$ and the AHA groups were found to be better than those of the 
control group. Similarly, there was no difference in fibroblast density between the groups on the $3^{\text {rd }}$ and the $7^{\text {th }}$ days. On day 14, fibroblast density was found to be less in the Madecassol ${ }^{\circledR}$ and the AHA groups compared to that of the control group. Angiogenesis was found to be less in the AHA and Madecassol ${ }^{\circledR}$ groups on the $3^{\text {rd }}$ and $14^{\text {th }}$ days compared to that of the control group. Neutrophil infiltration was found to be less in the AHA and Madecassol ${ }^{\circledR}$ groups on the $7^{\text {th }}$ day than that in the control group. Edema was found to be less in the $\mathrm{AHA}$ and the Madecassol ${ }^{\circledR}$ groups on the $3^{\text {rd }}, 7^{\text {th }}$ and $14^{\text {th }}$ days compared to the control group (Figure 2). The results are shown in Table 3.

Table 3. Comparison of Histological Parameters Between Groups.

\begin{tabular}{|c|c|c|c|c|c|}
\hline & $\begin{array}{l}\text { Epidermis } \\
\text { regeneration }\end{array}$ & $\begin{array}{l}\text { Fibroblast } \\
\text { density }\end{array}$ & Angiogenesis & $\begin{array}{l}\text { Neutrophil } \\
\text { infiltration }\end{array}$ & Edema \\
\hline \multicolumn{6}{|c|}{$3^{\text {rd day, mean (min.-max.) }}$} \\
\hline $\begin{array}{l}\text { Control } \\
\text { (Group 1) }\end{array}$ & 0 & 0 & $2.80(2-3)$ & $2.83(2-3)$ & $2.66(2-3)$ \\
\hline $\begin{array}{c}\text { Madecassol }^{\otimes} \\
\text { (Group 2) }\end{array}$ & $0.33(0-1)$ & 0 & $3.66(3-4)$ & $2.33(1-3)$ & $1.33(0-2)$ \\
\hline $\begin{array}{c}\text { AHA } \\
\text { (Group 3) }\end{array}$ & $0.16(0-1)$ & 0 & $3.50(2-4)$ & $2.50(1-3)$ & $1.50(1-2)$ \\
\hline P & $\begin{array}{c}1 \& 2 \& 3 \\
>0.05\end{array}$ & $\begin{array}{c}1 \& 2 \& 3 \\
>0.05\end{array}$ & $\begin{array}{c}* 1 \& 2<0.05 \\
* 1 \& 3<0.05 \\
2 \& 3>0.05\end{array}$ & $\begin{array}{c}1 \& 2 \& 3 \\
>0.05\end{array}$ & $\begin{array}{c}* 1 \& 2<0.05 \\
* 1 \& 3<0.05 \\
2 \& 3>0.05\end{array}$ \\
\hline
\end{tabular}

$7^{\text {th }}$ day, mean (min.-max.)

\begin{tabular}{|c|c|c|c|c|c|}
\hline $\begin{array}{l}\text { Control } \\
\text { (Group 1) }\end{array}$ & $0.5(0-1)$ & $2.33(1-3)$ & $3.16(2-4)$ & $2.16(1-3)$ & $2.33(1-3)$ \\
\hline $\begin{array}{c}\text { Madecassol }^{\circledR} \\
\text { (Group 2) }\end{array}$ & $1.16(1-2)$ & $2.66(2-3)$ & $3.50(3-4)$ & $1.33(0-3)$ & $1.50(1-2)$ \\
\hline $\begin{array}{c}\text { AHA } \\
\text { (Group 3) }\end{array}$ & $1.00(1-2)$ & $2.66(2-3)$ & $3.50(3-4)$ & $1.83(1-3)$ & $1.66(1-2)$ \\
\hline$P$ & $\begin{array}{c}1 \& 2 \& 3 \\
>0.05\end{array}$ & $\begin{array}{c}1 \& 2 \& 3 \\
>0.05\end{array}$ & $\begin{array}{c}1 \& 2 \& 3 \\
>0.05\end{array}$ & $\begin{aligned} * 1 \& 2<0.05 \\
* 1 \& 3<0.05 \\
2 \& 3>0.05\end{aligned}$ & $\begin{array}{l}* 1 \& 2<0.05 \\
* 1 \& 3<0.05 \\
2 \& 3>0.05\end{array}$ \\
\hline \multicolumn{6}{|c|}{$14^{\text {th }}$ day, mean (min.-max.) } \\
\hline $\begin{array}{l}\text { Control } \\
\text { (Group 1) }\end{array}$ & $1.66(1-2)$ & $2(1-3)$ & $2.16(1-2)$ & $0.5(0-1)$ & $0.83(0-2)$ \\
\hline $\begin{array}{c}\text { Madecassol }^{\circledR} \\
\text { (Group 2) }\end{array}$ & $2.66(2-3)$ & $1.5(1-2)$ & $1.66(1-2)$ & 0 & 0 \\
\hline $\begin{array}{c}\text { AHA } \\
\text { (Group 3) }\end{array}$ & $2.33(2-3)$ & $1.66(1-2)$ & $1.66(1-2)$ & 0 & $0.16(0-1)$ \\
\hline$P$ & $\begin{aligned} * 1 \& 2 & <0.05 \\
* 1 \& 3 & <0.05 \\
2 \& 3 & >0.05\end{aligned}$ & $\begin{array}{c}* 1 \& 2< \\
0.05 \\
* 1 \& 3< \\
0.05 \\
2 \& 3> \\
0.05\end{array}$ & $\begin{array}{c}* 1 \& 2<0.05 \\
* 1 \& 3<0.05 \\
2 \& 3>0.05\end{array}$ & $\begin{array}{c}1 \& 2 \& 3> \\
0.05\end{array}$ & $\begin{aligned} & * 1 \& 2<0.05 \\
& * 1 \& 3<0.05 \\
& 2 \& 3>0.05\end{aligned}$ \\
\hline
\end{tabular}

Min.: minimum; max.: maximum; AHA: Algan Hemostatic Agent

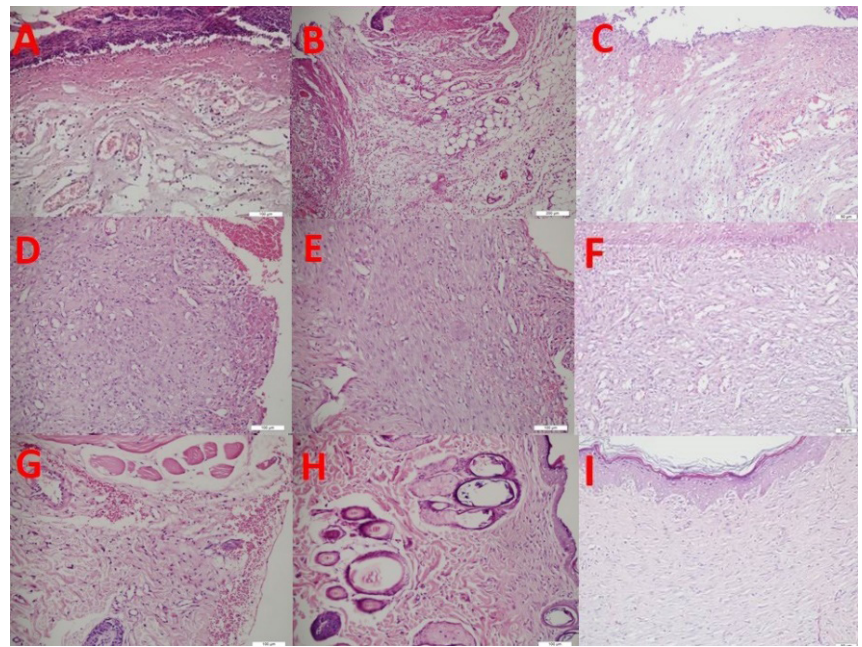

Figure 2. Histopathological view of the wound in the control, $A H A$ and Madecassol ${ }^{\circledR}$ groups, respectively. A, B, C: $3^{\text {rd }}$ day; D, E, F: $7^{\text {th }}$ day; $G, H, I: 14^{\text {th }}$ days. On the $3 r d$ day, histopathologic examination revealed acute inflammatory cell infiltration with intense bleeding in all groups. Intense edema is noted in the control group $(A, B, C)$. On the $7^{\text {th }}$ day, granulation tissue was rich in cells in the control group and the other two groups had less cellularity. On day 14, the connective tissue rich in healing area was observed in the Madecassol ${ }^{\circledR}$ and the AHA groups compared to the control group. In the control group, vascular granulation tissue is still present.

\section{DISCUSSION}

Many studies have clinically and histologically investigated the healing potential of natural products on incisional and excisional wound models. It has been shown that plants and extracts with pro-collagen syhthesis, antioxidant, antiinflammatory and antimicrobial activities have accelerated wound healing (4). AHA is a new local hemostatic agent and a herbal biopolymer. Its effectiveness on experimental bleeding models is being investigated (811). However, its effects on wound healing have not been investigated. Therefore, this study was planned to evaluate the potential effect of AHA with biochemical and histological parameters in the excisional wound model.

Based on the ethnobotanical use of plants, making scientific research in this direction is very important in revealing the products or medicines that will be used as primitive raw materials in the treatment (if the active compound is to be isolated). Proof of this effect of these plants, which are used by the public for wounding purposes, is of great importance when evaluated in this respect. As AHA will be used in bleeding areas, it will be directly related to wound healing. Therefore, its effect on wound healing was tested. There are many studies conducted in the literature about the effect of many other haemostatic agents on wound healing. In these studies, it has been shown that many hemostatic products have a positive effect on wound healing (13-15). In a study conducted by Akalin et al. (18) with a herbal hemostatic agent, it was reported that the hemostatic agent was superior to the control group in terms of wound contraction 
rates, type I / type III collagen ratio and inflammatory scoring in the dermal wound model.

AHA is an effective product in preclinical studies (8-11). Furthermore, the ability to produce AHA in powder and liquid forms is important in terms of ease of use in clinical practice. In splenectomy hemorrhage model with AHA, it is shown that it does not have intra-abdominal adhesion (8). Biopolymers are naturally occurring biomolecules synthesized by bacteria, plants and animals. Their bioactive properties such as antimicrobial, immune modulator and cell proliferative can create a micro-environment suitable for wound healing process (19).

AHA consists of a standardized mixture of 6 different plants. Several studies were carried out on this standard mixture of wound healing. Achillea millefolium has been shown to accelerate wound healing with its effect on collagen production, wound proliferation phase (20) and edema (21). Juglans regia has antioxidant, antimicrobial and wound healing activity $(22,23)$, Lycopodium clavatum has been shown to have potential effects on inhibition of ROS production and tissue repair associated signaling pathways during wound healing $(24,25)$. Viscum album accelerates cell migration (26). Vitis vinifera accelerates wound healing by acting on collagenation (27). Rubus caesius has high antioxidant potential (28). Wound healing activities of different Rubus species such as Rubus niveus (29), Rubus ellipticus (30), Rubus fairholmianus (31), Rubus sanctus (32) have also been reported.

In our study, the effect of liquid form of AHA on wound healing was examined histopathologically as well as by measurement of wound areas and hydroxyproline levels. Wound area measurement is a good indicator for monitoring wound healing (7). Collagen is synthesis by the healing tissue and the level of hydroxyproline in the tissue is an indicator of collagen concentration. As the concentration of hydroxyproline increases, wound healing accelerates (28). In our study, no significant difference was observed in hydroxyproline levels in the wound tissue of the AHA groups compared to the control group. Parallel to hydroxyproline levels, AHA did not cause a significant difference in wound closure compared to the control group. The effect of AHA on wound healing in terms of histopathological parameters was close to that of the Madecassol ${ }^{\circledR}$ group. However, positive histopathological findings were not reflected in macroscopic and biochemical findings.

As a result, when applied to wounds, AHA did not adversely affect wound healing and had a low positive effect compared to Madecassol ${ }^{\circledR}$. AHA may be used safely on excision wounds as a herbal product.

\section{CONCLUSION}

The present study affirms that AHA does not delay wound healing and has a low positive effect on wound healing in an excsion wound model. Further studies are needed to demonstrate the possible effects of AHA on different wound models such as burn and diabetic wounds.

\section{REFERENCES}

[1] Thiruvoth FM, Mohapatra DP, Kumar D, Chittoria SRK, Nandhagopal V. Current concepts in the physiology of adult wound healing. Plast Aesthet Res 2015; 2:250-256.

[2] Guo S, Di Pietro LA. Factors Affecting Wound Healing. J Dent Res 2010; 89(3):219-229.

[3] Krafts KP. Tissue repair: The hidden drama. Organogenesis 2010; 6(4):225-233.

[4] Ibrahim N, Wong SK, Mohamed IN, Mohamed N, Chin KY, ImaNirwana S, Shuid AN. Wound Healing Properties of Selected Natural Products. Int J Environ Res Public Health 2018; 15(11):2360.

[5] Aksoy H, Sen A, Sancar M, Sekerler T, Akakin D, Bitis L, Uras F, Kultur S, Izzettin FV. Ethanol extract of Cotinus coggygria leaves accelerates wound healing process in diabetic rats. Pharm Biol 2016a; 54(11):2732-2736.

[6] Aksoy H, Sancar M, Sen A, Okuyan B, Bitis L, Uras F, Akakin D, Cevik O, Kultur S, İzzettin FV. The effect of topical ethanol extract of Cotinus coggygria Scop. on cutaneous wound healing in rats. Nat Prod Res 2016b; 30(4):452-455.

[7] Aksoy H, Çevik Ö, Şen A, Göğer F, Şekerler T, Şener A. Effect of horse-chestnut seed extract on matrix metalloproteinase-1 and-9 during diabetic wound healing. J Food Biochem 2019; 43(3):e12758.

[8] Midi A, Ekici H, Kumandas A, Durmus O, Bodic B, Tiryaki M, Balik MS, Yeşilada E. Investigation of the effectiveness of algan hemostatic agent in bleeding control using an experimental partial splenectomy model in rats. Marmara Med J 2019a; 32(1):27-32.

[9] Midi A, Kumandaş A, Ekici $H$, Arda S, Karahan S, Şimşek $A$, Yeşilada $E$. Investigation of the effectiveness of algan hemostatic agent in renal venous bleeding model in rats. Eurasian J Med 2018a; 2:129-132.

[10] Midi A, Kumandas A, Ekici H, Bayraktar F, Karapirli K, Karahan $\mathrm{S}$, Turk $\mathrm{M}$, Ozyurek $\mathrm{H}$. Investigation of the efficacy of algan hemostatic agent in liver laceration model in rats. EJMO 2019b; 3(1):37-42.

[11] Midi A, Ozyurek H, Karahan S, Ekici H, Kumandas A, Turkmen I, Kocabas E, Turk M, Demirel O, Yesilada E. Investigation of efficacy of the plant based algan hemostatic agent in hepatectomy bleeding model in rats. EJMI 2018b; 2:195-201.

[12] Hickman DA, Pawlowski Cl, Sekhon UDS, Marks J, Gupta AS. Biomaterials and Advanced Technologies for Hemostatic Management of Bleeding. Adv Mater 2018; 30(4):1700859.

[13] Kaya H, Gokdemir MT, Sogut O. Effects of folk medicinal plant extract ankaferd blood stopper on burn wound healing. Acta Med Mediterr 2013; 29:497-502.

[14] Satar G, Cangül IT, Topal A, Oktay A, İnan K, Akgül MB. Effects of ankaferd blood stopper (ABS) and topical tripeptide copper complex (TCC) on wound healing in rats: An experimental study. Kafkas Univ Vet Fak Derg 2014; 20 (4):545-551.

[15] Aktaş A, Er N, Korkusuz P, Zeybek D, Onur MA, Tan G, Özdemir $O$, Karaismailoğlu E, Karabulut E. Ankaferd-induced early soft tissue wound healing in an experimental rat model. Turkiye Klinikleri J Med Sci 2013; 33(6):1344-1353. 
[16] Sener A, Cevik O, Doğan O, Altindiş N, Aksoy H, Okuyan B. The effects of topical melatonin on oxidative stress, apoptosis signals, and $\mathrm{p} 53$ protein expression during cutaneous wound healing. Turk J Biol 2015; 39(6):888-895.

[17] Reddy GK, Enwemeka CS. A simplified method for the analysis of hydroxyproline in biological tissues. Clin Biochem 1996; 29(3):225-229.

[18] Akalin C, Kuru S, Barlas AM, Kismet K, Kaptanoglu B, Demir A, Astarci HM, Ustun H, Ertas E. Beneficial effects of Ankaferd Blood Stopper on dermal wound healing: an experimental study. Int Wound J 2014; 11(1):64-68.

[19] Sahana TG, Rekha PD. Biopolymers: Applications in wound healing and skin tissue engineering. Mol Biol Rep 2018; 45(6):2857-2867.

[20] Hemmati AA, Arzi A, Amin M. Effect of Achillea millefolium extract in wound healing of rabbit. J Nat Rem 2002; 2(2):164167.

[21] Hajhashemi M, Ghanbari Z, Movahedi M, Rafieian M, Keivani A, Haghollahi F. The effect of Achillea millefolium and Hypericum perforatum ointments on episiotomy wound healing in primiparous women. J Matern Fetal Neonatal Med 2018; 31(1):63-69.

[22] Al-Nadaf AH, Seder NJ, Rayyan WA. Wound healing; antimicrobial and anti-oxidant activity for Jordanian Juglans Regia L. unripe fruits. J Innov Pharm Biol Sci 2018; 5(3):26-34.

[23] Taheri A, Mirghazanfari SM, Dadpay M. Wound healing effects of Persian walnut (Juglans regia L.) green husk on the incision wound model in rats. Eur J Transl Myol 2020; 30(1):210-218.

[24] Banerjee J, Biswas S, Madhu NR, Karmakar SR, Biswas SJ. $A$ better understanding of pharmacological activities and uses of phytochemicals of Lycopodium clavatum: A review. J Pharmacogn Phytochem 2014; 3(1):207-210.

[25] Das S, Das J, Paul A, Samadder A, Khuda-Bukhsh AR. Apigenin, a bioactive flavonoid from Lycopodium clavatum, stimulates nucleotide excision repair genes to protect skin keratinocytes from ultraviolet $\mathrm{B}$-induced reactive oxygen species and DNA damage. J Acupunct Meridian Stud 2013; 6(5):252-262.

[26] Kuonen R, Weissenstein U, Urech K, Kunz M, Hostanska K, Estko M, Heusser P, Baumgartner S. Effects of Lipophilic Extract of Viscum album L. and Oleanolic Acid on Migratory Activity of $\mathrm{NIH} / 3 \mathrm{T3}$ Fibroblasts and on HaCat Keratinocytes. Evid Based Complement Alternat Med 2013; 2013:718105.

[27] Shivananda Nayak B, Dan Ramdath D, Marshall JR, Isitor G, Xue $\mathrm{S}$, Shi J. Wound-healing properties of the oils of Vitis vinifera and Vaccinium macrocarpon. Phytother Res 2011; 25(8):12011208.

[28] Grochowski DM, Uysal S, Zengin G, Tomczyk M. In vitro antioxidant and enzyme inhibitory properties of Rubus caesius L., Int J Environ Heal Res 2019; 29(3):237-245.

[29] George BP, Parimelazhagan T, Sajeesh T, Saravanan S. Antitumor and wound healing properties of Rubus niveus Thunb. root. J Environ Pathol Tox Oncol 2014a; 33(2):145-158.

[30] George BP, Parimelazhagan T, Kumar YT, Sajeesh T. Antitumor and wound healing properties of Rubus ellipticus Smith. J Acupunct Meridian Stud 2015; 8(3):134-141.

[31] George BP, Parimelazhagan T, Chandran R. Anti-inflammatory and wound healing properties of Rubus fairholmianus Gard. root-An in vivo study. Ind Crop Prod 2014b; 54:216-225.

[32] Süntar I, Koca U, Keleş H, Akkol EK. Wound healing activity of Rubus sanctus Schreber (Rosaceae): Preclinical Study in Animal Models. Evid-Based Compl Alt Med 2011; 816156. 